\title{
TaqMan probe assays on different biological samples for the identification of three ambrosia beetle species, Xylosandrus compactus (Eichoff), X. crassiusculus (Motschulsky) and X. germanus (Blandford) (Coleoptera Curculionidae Scolytinae)
}

\author{
Domenico Rizzo ${ }^{1}$ (D) Daniele Da Lio ${ }^{2} \cdot$ Linda Bartolini $^{1} \cdot$ Chiara Salemi $^{2} \cdot$ Dalia Del Nista ${ }^{3} \cdot$ Antonio Aronadio $^{3}$.

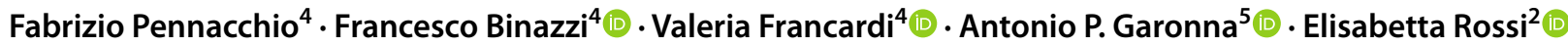

Received: 23 February 2021 / Accepted: 8 April 2021 / Published online: 10 May 2021

(c) The Author(s) 2021

\begin{abstract}
Molecular assays based on qPCR TaqMan Probes were developed to identify three species of the genus Xylosandrus, $X$. compactus, $X$. crassiusculus and $X$. germanus (Coleoptera Curculionidae Scolytinae). These ambrosia beetles are xylophagous species alien to Europe, causing damages to many ornamental and fruiting trees as well as shrubs. DNA extraction was carried out from adults, larvae and biological samples derived from insect damages on infested plants. For X. compactus, segments of galleries in thin infested twigs were cut and processed; in the case of X. crassiusculus, raw frass extruded from exit holes was used, while DNA of $X$. germanus was extracted from small wood chips removed around insect exit holes. The assays were inclusive for the target species and exclusive for all the non-target species tested. The LoD was $3.2 \mathrm{pg} / \mu \mathrm{L}$ for the frass of $X$. crassiusculus and $0.016 \mathrm{ng} / \mu \mathrm{L}$ for the woody matrices of the other two species. Both repeatability and reproducibility were estimated on adults and woody samples, showing very low values ranging between 0.00 and 4.11 . Thus, the proposed diagnostic assays resulted to be very efficient also on the woody matrices used for DNA extraction, demonstrating the applicability of the protocol in the absence of dead specimens or living stages.
\end{abstract}

Keywords Black twig-borer $\cdot$ Granulate ambrosia beetle $\cdot$ Black timber bark beetle $\cdot$ Molecular diagnostics

Elisabetta Rossi

elisabetta.rossi@unipi.it

Domenico Rizzo

domenico.rizzo@ regione.toscana.it

Daniele Da Lio

dalia.delnista@regione.toscana.it

Linda Bartolini

linda.bartolini@regione.toscana.it

Chiara Salemi

chiarasalemi93@gmail.com

Dalia Del Nista

daniele.dalio@hotmail.com

Antonio Aronadio

antonio.aronadio@regione.toscana.it

Fabrizio Pennacchio

fabrizio.pennacchio@crea.gov.it

Francesco Binazzi

francesco.binazzi@crea.gov.it
Valeria Francardi

valeria.francardi@crea.gov.it

Antonio P. Garonna

garonna@unina.it

1 Laboratory of Phytopathological Diagnostics and Molecular Biology, Plant Protection Service of Tuscany, Via Ciliegiole 99, 51100 Pistoia, Italy

2 Department of Agricultural, Food and Agro-Environmental Sciences, University of Pisa, Via del Borghetto 80, 56124 Pisa, Italy

3 Laboratory of Phytopathological Diagnostics, Plant Protection Service of Tuscany, via delle Colline, Collesalvetti, 57014 Livorno, Italy

4 CREA-Research Centre for Plant Protection and Certification, via Lanciola 12/A, 50125 Florence, Italy

5 Department of Agricultural Sciences, University of Naples Federico II, 80055 Portici, Italy 


\section{Introduction}

The subfamily Scolytinae (Coleoptera: Curculionidae) includes more than 6000 species worldwide divided into 26 tribes and 247 genera (Vega and Hofstetter 2015). Scolytinae are xylophagous beetles colonizing the wood at phloem (phleophagous species) or xylem level (xylomycetophagous species) of many ornamental and forest plants (Kirkendall and Biedermann 2015). In recent years, Europe and the Americas have been affected by the introduction and establishment of numerous exotic species of the Xyleborini tribe, which caused growing concerns for native biodiversity and forest resources (Kirkendall and Faccoli 2010; Grousset et al. 2020). Their ability to escape phytosanitary controls due to their cryptobiotic behaviour, their capacity to establish in the new environment due to their reproductive behavior, their large polyphagy and the increasing global trade of wood (Reed and Muzika 2010; Rassati et al. 2016a; Smith et al. 2020) make Xyleborini a potentially invasive taxon.

The genus Xylosandrus Reitter, 1913, is a large genus of the Xyleborini ambrosia beetles presently including 40 species widespread in tropical and temperate areas (Dole and Cognato 2010; Dole et al. 2010). In Europe and North America, $X$. compactus, $X$. crassiusculus and $X$. germanus have been listed among the species of major concern (Rassati et al. 2016b).

The first report for Europe of X. compactus (the shothole borer or black twig-borer) dates back to 2012, in urban parks of the Campania and Tuscany regions (Italy) (Garonna et al. 2012; Pennacchio et al. 2012a) but its current distribution in Italy has further expanded (Francardi et al. 2017). To date, the species is established in France, Greece as well as Monaco and it is currently under eradication in Spain (CABI 2020; EPPO 2020). X. compactus shows a highly invasive potential and represents a serious threat in the Mediterranean Basin due to its wide host range and multitrophic interactions (Vannini et al. 2017; Gugliuzzo et al. 2019; Contarini et al. 2020).

As ambrosia beetle, it is associated with the primary symbiont Ambrosiella xylebori (Bateman et al. 2016; Vannini et al. 2017; Gugliuzzo et al. 2020) and with nonmycangial fungi such as Fusarium solani (Bosso et al. 2012), canker and dieback pathogens of woody hosts (Gugliuzzo et al. 2020) and several other fungal species (Morales-Rodriguez et al. 2021).

Xylosandrus crassiusculus (the granulate ambrosia beetle) is a polyphagous species, native to tropical and subtropical regions of Asia, but now present in some European countries (limited areas of France, Italy, Slovenia, Spain), Africa, American continent, and Oceania (Pennacchio et al. 2003; CABI 2019a; EPPO 2020). The host plants include many forest and ornamental woody species as well as fruiting trees of economic importance. Infested plants show wilting, shoot breakage and branch dieback. $X$. crassiusculus is also included in Annex II of the Commission Implementing Regulation (EU) 2019/2072 as a non-Europeam bark beetle (EFSA 2019).

The black timber bark beetle $X$. germanus is an invasive ambrosia beetle native to East Asia, from the Kuril Islands to Vietnam, presently occurring in Europe, Russia (European and Asiatic Regions), Turkey and North America (Galko et al. 2019; Dzurenko et al. 2020; CABI 2019b; EPPO 2020). The species is polyphagous, and the wide range of its host plants includes many ornamentals, forest (broadleaf and more rarely coniferous species) and fruiting trees (Weber and McPherson 1983). Its diffusion across Europe has accelerated since 2000, probably because of climate change and the increased use of wood as packaging material (Galko et al. 2019). X. germanus is a xylomycetophagous species whose larvae develop freely in the maternal gallery feeding on the fungus growing on the walls; inside mycangia and maternal gallery, fungi of the genus Ambrosiella prevail as symbiotic organisms although many other fungi, yeasts and bacteria can be found (Mayers et al. 2015; Tuncer et al. 2018). The mechanism of host plant selection is mediated by the emission of stress-related volatiles (Ranger et al. 2010, 2015).

The economic importance of $X$. germanus is relevant in the USA, where it causes consistent damages in nurseries (Ranger et al. 2016), apple orchards (Agnello et al. 2017) and black walnut stands (Katovich, 2004); in Europe, its importance is related to outbreaks in forests (Bruge, 1995; Galko et al. 2019; Inward, 2020) and in the Mediteranean maquis (Contarini et al. 2020) but damages have been observed also in Italy on walnut (Stergulc et al. 1999) and chestnut plantations (Dutto et al. 2018). Moreover, X. germanus is considered a threat to the biodiversity of autoctonous Scolytinae communities (Henin and Versteirt 2004; Bouget and Noblecourt 2005), presumably because its niche overlaps with that of the indigenous species.

The three species of Xylosandrus may coexist in complex ecosystems with a high level of plant diversity (Contarini et al. 2020).

Taxonomic keys based on morphological characters of adults are available for Xylosandrus identification (Dole and Cognato 2010; Gallego et al. 2017; Garonna et al. 2012; Francardi et al. 2017), but their use may be complex as it requires a specific entomological expertise; for the larvae, identification based on morphological characters can be also difficult due to the lack of suitable keys. Therefore, the possibility of using a molecular method to univocally identify the species could be a functional tool in the operative practice, especially in areas where the insect has not been yet detected 
or in the niches where other Xylosandrus species can overlap their distribution (Francardi et al. 2017; Contarini et al. 2020). Molecular identification of $X$. compactus (Kiran et al. 2019), X. crassiusculus (Landi et al. 2017) and X. germanus (Cognato et al. 2020) has been established based on the mitochondrial cytochrome c oxidase I.

In this study, three different molecular assays aimed at identifying $X$. compactus, $X$. crassiusculus, and $X$. germanus based on qPCR with TaqMan Probe technology have been developed for a rapid and reliable identification of these invasive pests from larvae, adults, and wood chips/frass. Such tools could be very useful in phytosanitary practice where specific, and unambiguous identification methods can greatly accelerate inspection tasks conducted by Plant Protection Organizations at the national and international level, especially if they can operate with shared identification protocols.

\section{Materials and methods}

\section{Biological samples}

Adults and larvae of $X$. compactus, $X$. crassiusculus and $X$. germanus were collected during routine monitoring inspections carried out by the Phytosanitary Service in Tuscany, or by other research institutions in the respective Regions, as shown in Table 1. Larvae and adults were stored in $70 \%$ ethanol solution at room temperature, until use. The third type of samples was obtained from infested plants, in a different way for each of the three species due to the different diameters of infested twigs or trunks. For X. compactus, samples were collected from infested thin twigs (diameter of about $1 \mathrm{~cm}$ ) of Laurus nobilis and Rhododendron sp., cutting small sections of wood close to the adult exit holes (Fig. 1a). For X. crassiusculus, samples were obtained collecting the frass from the tubes sticking out of the holes on infested logs of Juglans nigra (Fig. 1b) imported from USA and intercepted at the entry point of Leghorn. Adults and larvae of the wood borer inside the galleries were allowed to confirm the identification. In the case of X. germanus, samples were obtained in a different way, removing small wood chips (about $1 \mathrm{~cm}$ long) that included the last part of the insect galleries and the exit hole in an infested trunk of Lagerstroemia indica (Fig. 1c). All these samples were stored at room temperature in the lab until use, for a period ranging from 2 to 8 months.

The non-target insects (adults and/or larvae) used as comparison were part of the biomolecular collection of the Phytopathological Lab of the Phytosanitary Service of the Tuscany Region, Italy. The non-target samples used to test the specificity of the proposed method were DNAs extracted from frass of other xylophagous species. The non-target insects and frass are listed in Table 1.

\section{DNA extraction from target and non-target samples}

Genomic DNA from all target insect and wood chips or frass samples was extracted using a modified protocol based on the CTAB one suggested by Li et al. (2008), until the addition of chloroform and the subsequent centrifugation at $11,500 \times g$ for $5 \mathrm{~min}$. An aliquot of $600 \mu \mathrm{L}$ of the upper phase was purified using the Maxwell ${ }^{\circledR}$ RSC PureFood GMO and Authentication Kit in combination with the automated purificator MaxWell 16 (Promega, Madison, WI, USA). Details of the purification have been previously described (Rizzo et al. 2020a, b). For adult and larvae samples, single specimens were processed, for the woody samples, $500 \mathrm{mg}$ of each sample were used in the extraction.

The DNA of non-target samples was extracted using the same procedure described for target samples but in different times.

The quality of the extracted DNA was assayed in qPCR after a dilution 1:20 of DNA in $\mathrm{ddH}_{2} \mathrm{O}$; a dual-labeled probe targeting a highly conserved region of the $18 \mathrm{~S}$ rDNA was used in the reaction (Ioos et al. 2009). The amplificability tests carried out in this way served as control of the extractions and allowed to verify the presence of inhibitors in relation to both the $\mathrm{Cq}$ detected and the slope of the relative amplification curves.

\section{Design of primers and probe and relative optimization}

The Oligo Architect Online (Sigma-Aldrich) software was used to design the primer pairs and probes, targeting the conserved sequences of $X$. compactus, $X$. crassiusculus and $X$. germanus genome calculating the product size, the melting temperature and primer length. The absence of secondary structure was also considered when possible. For the development of the real-time probe method, the sequence used for each of the tested species is shown in Table 2.

An in-silico test of the primer pairs was then performed with the BLAST ${ }^{\circledR}$ (Basic Local Alignment Search Tool: http://www.ncbi.nlm.nih.gov/BLAST), software to assess the specificity of the designed primer pairs and probe. The primers/probes used in this study for real-time Probe protocol, are reported in Table 3.

The in-silico specificity was further verified by searching for the most related nucleotide sequences by using the BLAST software, using as query the expected amplicons of the probe qPCR protocol. The sequences were aligned

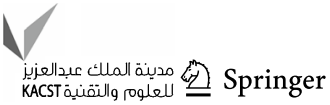


Table 1 Target and non-target samples (adults and/or larvae) and woody samples used for DNA extraction

\begin{tabular}{|c|c|c|c|c|c|}
\hline & $\begin{array}{l}\text { Internal } \\
\text { sample } \\
\text { number }\end{array}$ & Order & Fam/subfam & Species & Matrix/life stage \\
\hline \multirow[t]{36}{*}{ Non target samples } & 1 & Lepidoptera & Cossidae & Cossus cossus Linnaeus & Frass (from Quercus sp) \\
\hline & 2 & & & Cossus cossus Linnaeus & Larva \\
\hline & 3 & Coleoptera & Cerambycidae & Anoplophora chinensis Förster & Frass (from Populus spp) \\
\hline & 4 & & & Anoplophora chinensis Förster & Larva \\
\hline & 5 & & & Anoplophora chinensis Förster & Larva \\
\hline & 6 & & & $\begin{array}{l}\text { Anoplophora glabripennis (Motschul- } \\
\text { sky) }\end{array}$ & Frass (from Platanus spp) \\
\hline & 7 & & & $\begin{array}{l}\text { Anoplophora glabripennis (Motschul- } \\
\text { sky) }\end{array}$ & Adult \\
\hline & 8 & & & $\begin{array}{l}\text { Anoplophora glabripennis (Motschul- } \\
\text { sky) }\end{array}$ & Larva \\
\hline & 9 & & & $\begin{array}{l}\text { Anoplophora glabripennis (Motschul- } \\
\text { sky) }\end{array}$ & Egg \\
\hline & 10 & & & Aromia bungii (Faldermann) & Frass (from Prunus spp) \\
\hline & 11 & & & Aromia bungii (Faldermann) & Frass (from Prunus spp) \\
\hline & 12 & & & Aromia bungii (Faldermann) & Larva \\
\hline & 13 & & & Aromia moschata (Linnaeus) & Adult \\
\hline & 14 & & & Cerambyx cerdo Linnaeus & Adults \\
\hline & 15 & & & Cerambyx scopolii Fuessly & Adults \\
\hline & 16 & & & Cerambyx welensii Küster & Adult \\
\hline & 17 & & & Lepturges confluens (Haldeman) & Larva \\
\hline & 18 & & & Monochamus galloprovincialis Olivier & Adult \\
\hline & 19 & & & Monochamus sutor Linnaeus & Larva \\
\hline & 20 & & & Morimus asper (Sulzer) & Adult \\
\hline & 21 & & & Saperda carcharias (Linnaeus) & Adult \\
\hline & 22 & & & Saperda punctata (Linnaeus) & Adult \\
\hline & 23 & & & Saperda scalaris (Linnaeus) & Adult \\
\hline & 24 & & & Saperda tridentata Olivier & Larva \\
\hline & 25 & & & Saperda tridentata Olivier & Adult \\
\hline & 26 & & Scolytinae & Hylurgus ligniperda (Fabricius) & Adult \\
\hline & 27 & & & Ips sexdentatus Boern & Adult \\
\hline & 28 & & & Orthotomicus erosus (Wollaston) & Adult \\
\hline & 29 & & & Pityophthorus juglandis Blackman & Frass \\
\hline & 30 & & & Pityophthorus juglandis Blackman & Adult \\
\hline & 31 & & & Pityophthorus pubescens (Marsham) & Adult \\
\hline & 32 & & & Tomicus destruens (Wollaston) & Adult \\
\hline & 33 & & & Xyleborinus saxesenii Ratzeburg & Adult \\
\hline & 34 & & & Xyleborus dispar Fabricius & Adult \\
\hline & 35 & & & Xyleborus monographus (Fabricius) & Adult \\
\hline & 36 & & Silvanidae & Silvanus muticus Sharp & Larva \\
\hline \multirow[t]{7}{*}{ Target samples } & 37 & Coleoptera & & X. compactus (Eichhoff) & Adults \\
\hline & 38 & Scolytinae & & X. compactus (Eichhoff) & Larvae \\
\hline & 39 & & & X. compactus (Eichhoff) & Sections of wood (from Laurus nobilis) \\
\hline & 40 & & & X. compactus (Eichhoff) & Sections of wood (from Laurus nobilis) \\
\hline & 41 & & & $X$. crassiusculus (Motschulsky) & Adults \\
\hline & 42 & & & X. crassiusculus (Motschulsky) & Larvae \\
\hline & 43 & & & X. crassiusculus (Motschulsky) & Frass (from Juglans nigra) \\
\hline
\end{tabular}




\begin{tabular}{|c|c|c|c|c|}
\hline $\begin{array}{l}\text { Internal } \\
\text { sample } \\
\text { number }\end{array}$ & Order & Fam/subfam & Species & Matrix/life stage \\
\hline 44 & & & X. germanus (Blandford) & Adults \\
\hline 45 & & & X. germanus (Blandford) & Larvae \\
\hline 46 & & & X. germanus (Blandford) & Wood chips (from Lagerstroemia sp) \\
\hline
\end{tabular}

Fig. 1 a $X$. compactus, $\mathbf{b} X$. Crassiusculus, $\mathbf{c} X$. germanus. On the left, the damage caused by the three xylophagous species on twigs or trunks; on the right, a detail of the samples used for DNA extraction
Table 2 Primer sequences of the three Xylosandrus species used in this study

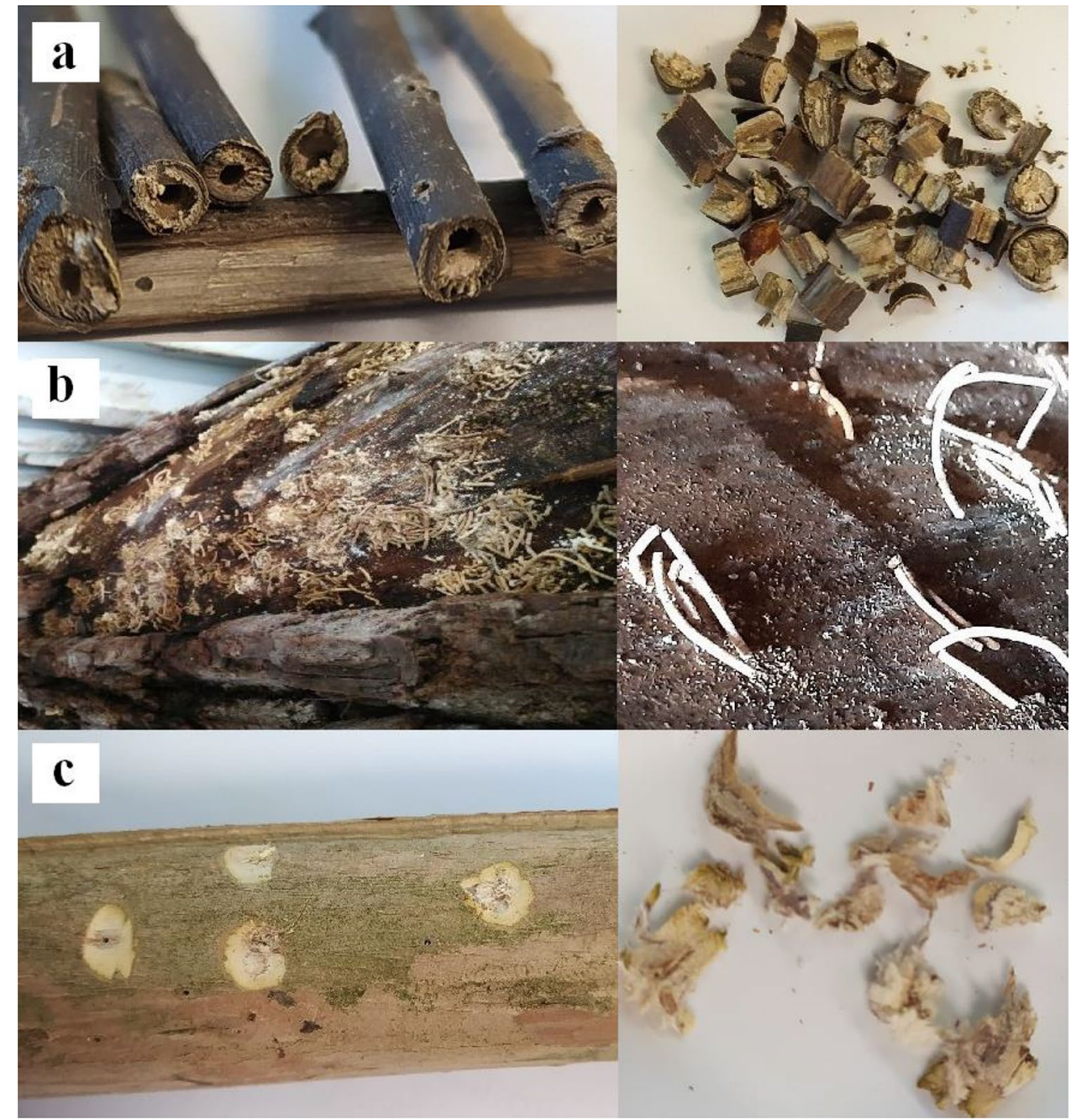

\begin{tabular}{lll}
\hline Organism & Description genomic region & Sequence number \\
\hline X. compactus & BMNH 1274291 mitochondrion, partial genome & KT696209.1 \\
X. crassiusculus & BMNH 1043087 mitochondrion, complete genome & KX035196.1 \\
X. germanus & Mitochondrion, complete genome & KX035202.1 \\
\hline
\end{tabular}

using the MAFFT program (Katoh and Standley 2013) implemented within the software Geneious ${ }^{\circledR}$ 10.2.6 (Biomatters, http://www.geneious.com). The results are shown in Fig. 2a-c for the three species of Xylosandrus spp.

\section{qPCR protocols}

To determine the optimal annealing temperatures, for all developed protocols, the temperature gradients from 50 to 
Table 3 Primers and probe designed and used in qPCR

\begin{tabular}{|c|c|c|c|c|}
\hline Species & Primer pair and probes & Lenght & Sequence & $\begin{array}{l}\text { Product } \\
\text { size } \\
\text { (bp) }\end{array}$ \\
\hline \multirow[t]{3}{*}{ X. compactus } & Xcomp_5117F & 20 & CGTGTAAGAGTTGCGTTGTC & \multirow[t]{3}{*}{143} \\
\hline & Xcomp_5229R & 20 & GGGTATGTTCTCCCTTGAGG & \\
\hline & Xcomp_5229P & 27 & Cy5 - TCATTCTGAGGTGCCACTGTCATCACA- BHQ2 & \\
\hline \multirow[t]{3}{*}{$X$. crassiusculus } & Xcrass_2693F & 20 & GCCCTTTGAATGTGGATTTG & \multirow[t]{3}{*}{116} \\
\hline & Xcrass_2808R & 25 & GGAGGAATAGTGTTAATTCAACATC & \\
\hline & Xcrass_2721P & 24 & FAM - AACTCAGCTCGCCTACCATTCTCT - BHQ1 & \\
\hline \multirow[t]{3}{*}{ X. germanus } & Xgerm_3354F & 18 & TCCTCGTCAATTGAATGA & \multirow[t]{3}{*}{89} \\
\hline & Xgerm_3442R & 19 & CCACATTAGAAGGTTGAAG & \\
\hline & Xgerm_3384P & 22 & FAM_TCGCCAGCAGAACACAGATACA_BHQ1 & \\
\hline
\end{tabular}

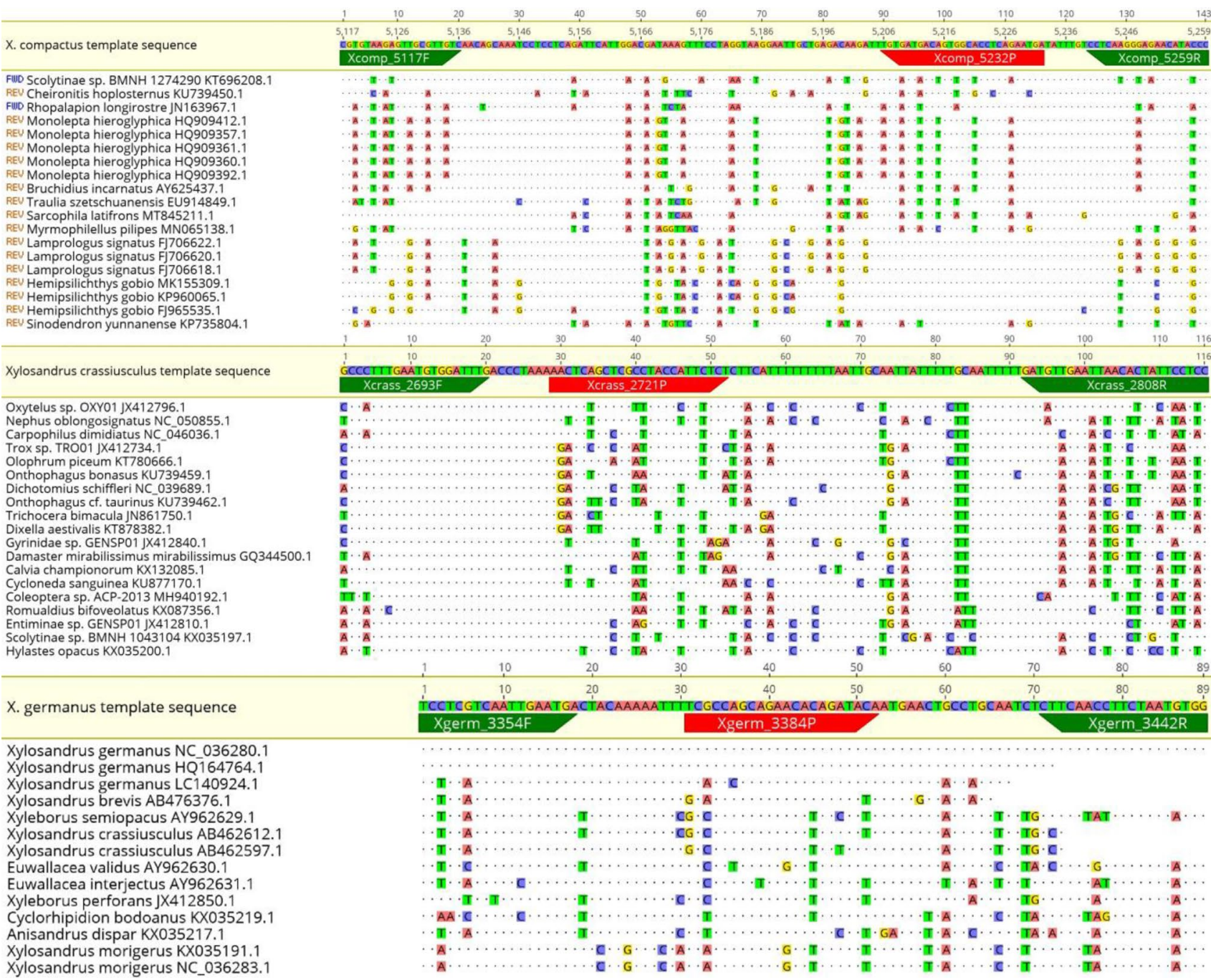

Fig. 2 a X. compactus, $\mathbf{b}$ X. crassiusculus, $\mathbf{c}$ X. germanus. Alignment of the in-silico amplicons to the similar sequences of other organisms present in GenBank using the probe qPCR protocol similarity values 
Table 4 Qualitative and quantitative parameters of DNA extractions from different matrices (adults, larvae and frass) for each protocol developed in this study

\begin{tabular}{llccc}
\hline Parameter & Matrix & X. compactus & X. crassiusculus & X. germanus \\
\hline DNA conc \pm SD (ng/ul) & Adults & $202.6 \pm 16.3$ & $168.4 \pm 45.2$ & $192.9 \pm 24.6$ \\
& Larvae & $321.5 \pm 25.1$ & $265.1 \pm 12.5$ & $187.3 \pm 2.1$ \\
& Frass/wood chips & $192.9 \pm 24.6$ & $187.3 \pm 2.1$ & $98.5 \pm 12.5$ \\
$($ A260/280) & Adults & $2.0 \pm 0.1$ & $2.0 \pm 0.2$ & $1.9 \pm 0.5$ \\
& Larvae & $2.0 \pm 0.4$ & $2.0 \pm 0.2$ & $2.0 \pm 0.3$ \\
Cq (18S rRNA) & Frass/wood chips & $1.8 \pm 0.2$ & $1.9 \pm 0.3$ & $1.9 \pm 0.2$ \\
& Adults & $17.9 \pm 2.1$ & $16.6 \pm 1.7$ & $16.8 \pm 1.4$ \\
& Larvae & $14.6 \pm 0.8$ & $14.9 \pm 1.2$ & $14.6 \pm 1.4$ \\
& Frass/wood chips & $21.6 \pm 1.5$ & $23.7 \pm 2.4$ & $24.9 \pm 1.8$ \\
\hline
\end{tabular}

The values for the three species of Xylosandrus genus are reported
$60{ }^{\circ} \mathrm{C}$ were tested on 10 DNA samples extracted from two adults and two woody samples of $X$. compactus, $X$. crassiusculus and $X$. germanus. Oligos and probes were used at different concentrations: $0.2 \mu \mathrm{M}, 0.3 \mu \mathrm{M}$ and $0.4 \mu \mathrm{M}$ each. For each target DNA sample, positive and negative amplification controls were included in each qPCR run. Samples were tested as technical duplicates and tests were repeated when unclear or contradictory results were obtained. The amplification reactions in qPCR Probe were performed with a CFX96 (Biorad, Hercules, CA) thermocycler in a final volume of $20 \mu \mathrm{L}$. Data obtained were analyzed with CFX Maestro 1.0 software using automatic thresholds and baselines for FAM and CY5.

In all probe assays, samples were considered positive when the correspondent qPCR curves showed a clear inflection point and an increasing kinetics, and $\mathrm{Cq}$ values $<35$.

\section{Validation of the method for the qPCR Probe}

Due to the possibility of using the test in routine diagnostics, performance criteria such as analytical sensitivity, analytical specificity, repeatability and reproducibility were determined. Validation was performed according to EPPO standard PM7/98 (4) 2019 for insect samples (larvae and adults) and for woody samples in each protocol assayed. In all test performed, the parameters true positives, false negatives, false positives and true negatives were considered according to EPPO standard (EPPO 2019).

The evaluation of the analytical sensitivity (limit of detection, LoD) was estimated in 1:5 serial dilutions for all qPCR protocol with TaqMan Probe for both adult and "artificial" frass samples. These last samples were obtained mixing $5 \mathrm{ng} /$ $\mu \mathrm{L}$ of DNA extracted from larvae of each species to DNA from frass (on Juglans nigra) of a non-target species (Pityophthorus juglandis) diluted at $50 \mathrm{ng} / \mu \mathrm{L}$. Three replicates were used using the DNA extracts diluted to $5 \mathrm{ng} / \mu \mathrm{L}$. The evaluation range for all protocols studied was included between $10 \mathrm{ng} /$ $\mu \mathrm{L}$ and $25.6 \mathrm{fg} / \mu \mathrm{L}$. All measurements were made using the QIAxpert system (QIAGEN, Hilden, Germany).

The repeatability was tested on ten DNA samples extracted from adults and woody portions (environmental frass, sections of infested twigs and wood chips collected in the field for each of the three ambrosia beetle species as previously described). The DNA samples were diluted at a concentration of $5 \mathrm{ng} / \mu \mathrm{l}$, with two independent extractions performed on each sample. The protocol of reproducibility was like the one used to test repeatability, but two different operators carried out the assays on different days.

\section{Results}

\section{DNA extraction}

The results of DNA extraction from the different matrices (adults, larvae and wood chips/frass) of the three species of Xylosandrus are shown in Table 4.

\section{Optimization of the Probe qPCR assay conditions}

The optimal mix reaction for each protocol developed in this study on Xylosandrus species included $10 \mu \mathrm{L}$ of $2 \times$ QuantiNova Probe PCR Master Mix (QIAGEN, Hilden, Germany) with $0.4 \mu \mathrm{M}$ of primers and a $0.2 \mu \mathrm{M}$ probe concentration. The optimal annealing temperatures were equal to $55^{\circ} \mathrm{C}$, $56{ }^{\circ} \mathrm{C}$ and $58{ }^{\circ} \mathrm{C}$ for $X$. compactus, $X$. crassiusculus, and $X$. germanus, respectively. There were negligible differences in $\mathrm{Cq}$ values between different concentrations of primers (300 and $500 \mathrm{nM}$ ) or probe (150 and $250 \mathrm{nM})$.

The qPCR conditions consisted of an initial denaturation at $95^{\circ} \mathrm{C}$ for $2 \mathrm{~min}$, followed by 40 cycles of $95^{\circ} \mathrm{C}$ for $10 \mathrm{~s}$, and $55{ }^{\circ} \mathrm{C}$ for $X$. compactus samples, $56{ }^{\circ} \mathrm{C}$ for $X$. crassiusculus samples and $58^{\circ} \mathrm{C}$ for $X$. germanus for $40 \mathrm{~s}$ (Fig. 3a-c). 
Fig. 3 a $X$. compactus, $\mathbf{b} X$. crassiusculus, $\mathbf{c} X$. germanus. Amplification curves of qPCR Probes (squares: adults, without symbols: larvae, triangles: woody samples). DNA extracts of adults, larvae and woody samples were diluted at $10 \mathrm{ng} /$ $\mu \mathrm{L}$
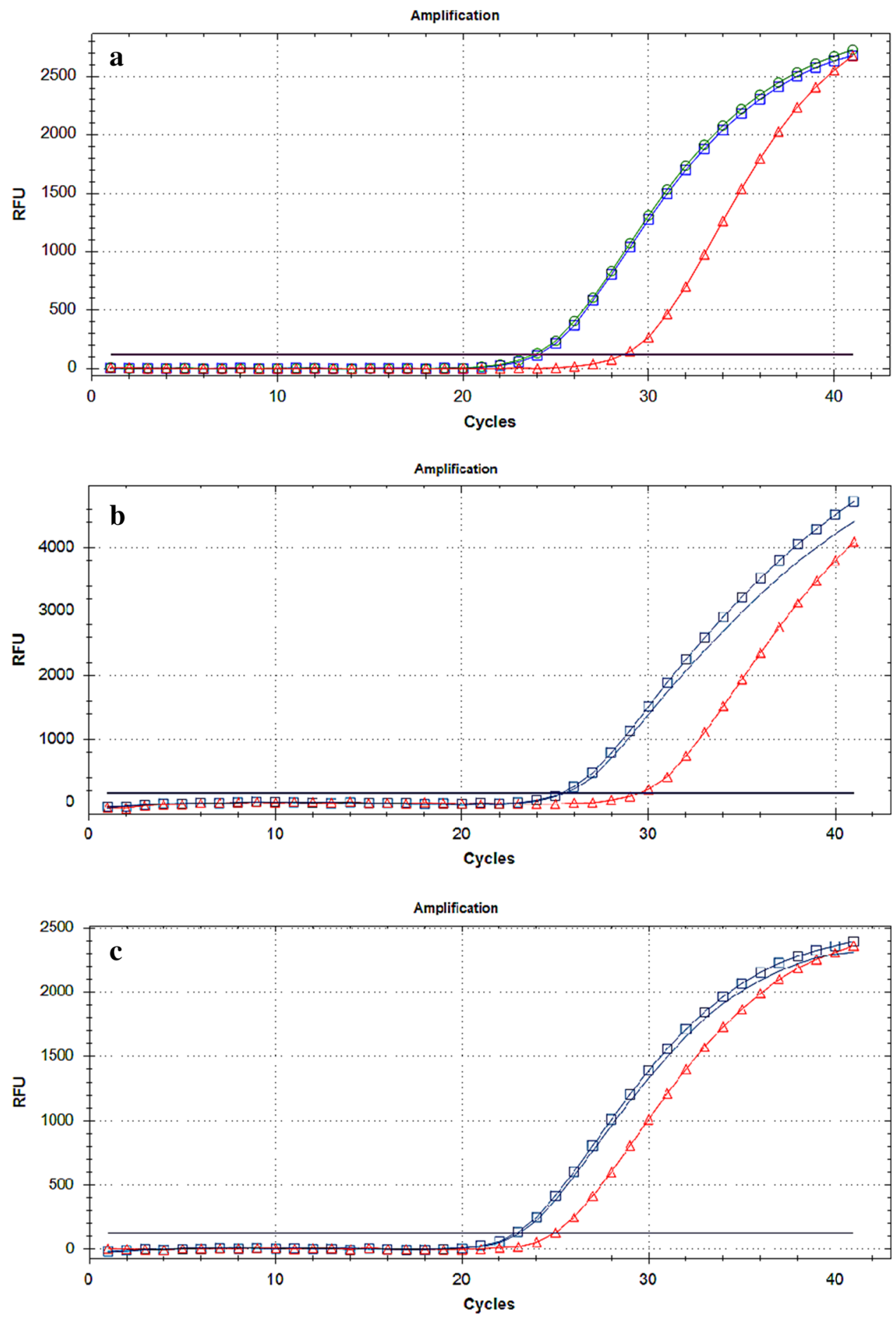


\section{Validation method}

The assays were inclusive for $X$. compactus, $X$. crassiusculus and $X$. germanus, and exclusive towards the non-target organisms tested. All target specimens were correctly identified using the specific test and no false-positive results were obtained for non-target organisms, resulting in a $100 \%$ diagnostic specificity, diagnostic sensitivity and accuracy. The test runs yielded the same qualitative results for all assayed samples and were not influenced by variation in assay conditions. The results are shown in Table 5.

Adult DNA samples of $X$. compactus and $X$. crassiusculus showed an identical LoD value of $3.2 \mathrm{pg} / \mu \mathrm{L}$, while the analytical sensitivity of $X$. germanus was $0.016 \mathrm{ng} / \mu \mathrm{L}$.

The woody matrix DNAs had different LoD values: in fact, the analytical sensitivity for $X$. compactus and X. germanus was the same $(0.016 \mathrm{ng} / \mu \mathrm{L})$, while for $X$. crassiusculus the LoD was $3.2 \mathrm{pg} / \mu \mathrm{L}$, lower than the value observed for adult samples.

The analytical sensitivity of assays for the three Xylosandrus species is shown in Figs. 4 and 5 where the amplification curves at the different dilutions and the respective standard curves are reported.

Repeatability and reproducibility were estimated for the three Xylosandrus species on adults and woody samples, which showed very low values (Teter and Steffen 2017). In fact, the repeatability values, as well as the reproducibility values measured as standard deviation (SD), varied between 0.00 and 4.11 (Table 6).

\section{Discussion}

Global trade and the use of wood as packaging material contributed to an accelerated rate of dispersal of ambrosia beetles in many parts of the world (Rassati et al. 2015; Meurisse et al. 2018). Major economic and ecological damages caused by the new invaders represent serious threats, therefore, timely species detection and identification is necessary (Blaser et al. 2018; Poland and Rassati 2019; Cognato et al. 2020).

During field monitoring and inspection activities, the availability of easy-to-handle morphological taxonomic keys could be crucial for the identification of the invasive species. In the case of the Xylosandrus, such taxonomic keys are available, although reserved to skilled users (Dole and Cognato 2010; Francardi et al. 2017), but their limit is the lack of morphological characters suitable to unambiguously identify the early instars of the genus, a problem widely common in xylophagous species (Pennacchio et al. 2012b; Wu et al. 2017).
Table 5 Analytical sensitivity (LoD) assays using 1:5 serial dilutions (from $10 \mathrm{ng} / \mu \mathrm{L}$ to $25.6 \mathrm{fg} / \mu \mathrm{L})$ from insect adult

\begin{tabular}{|c|c|c|c|c|}
\hline Samples & Dilutions 1:5 & $\begin{array}{l}\text { qPCR probe } \\
X . \text { compactus } \\
\mathrm{Cq} \text { mean } \pm \mathrm{SD}\end{array}$ & $\begin{array}{l}\text { qPCR probe } \\
X . \text { crassiusculus } \\
\text { Cq mean } \pm \mathrm{SD}\end{array}$ & $\begin{array}{l}\text { qPCR probe } \\
X . \text { germanus } \\
\text { Cq mean } \pm \mathrm{SD}\end{array}$ \\
\hline \multirow[t]{9}{*}{ Adults } & $10 \mathrm{ng} / \mu \mathrm{L}$ & $22.19 \pm 0.05$ & $22.55 \pm 0.89$ & $26.38 \pm 0.28$ \\
\hline & $2.0 \mathrm{ng} / \mu \mathrm{L}$ & $24.32 \pm 0.09$ & $24.86 \pm 1.02$ & $28.81 \pm 0.07$ \\
\hline & $0.4 \mathrm{ng} / \mu \mathrm{L}$ & $26.63 \pm 0.08$ & $28.69 \pm 1.20$ & $31.18 \pm 0.03$ \\
\hline & $0.08 \mathrm{ng} / \mu \mathrm{L}$ & $29.08 \pm 0.07$ & $30.09 \pm 0.05$ & $33.55 \pm 0.14$ \\
\hline & $0.016 \mathrm{ng} / \mu \mathrm{L}$ & $31.70 \pm 0.30$ & $32.47 \pm 0.04$ & $35.58 \pm 0.27$ \\
\hline & $3.2 \mathrm{pg} / \mu \mathrm{L}$ & $33.54 \pm 0.47$ & $34.42 \pm 0.43$ & - \\
\hline & $0.64 \mathrm{pg} / \mu \mathrm{L}$ & - & - & - \\
\hline & $0.128 \mathrm{pg} / \mu \mathrm{L}$ & - & - & - \\
\hline & $25.6 \mathrm{fg} / \mu \mathrm{L}$ & - & - & - \\
\hline \multirow[t]{9}{*}{ Wood chips/frass } & $10 \mathrm{ng} / \mu \mathrm{L}$ & $24.01 \pm 0.12$ & $22.96 \pm 0.12$ & $26.70 \pm 0.14$ \\
\hline & $2.0 \mathrm{ng} / \mu \mathrm{L}$ & $26.36 \pm 0.06$ & $25.08 \pm 0.07$ & $28.59 \pm 0.06$ \\
\hline & $0.4 \mathrm{ng} / \mu \mathrm{L}$ & $28.64 \pm 0.11$ & $27.25 \pm 0.11$ & $30.92 \pm 0.10$ \\
\hline & $0.08 \mathrm{ng} / \mu \mathrm{L}$ & $31.14 \pm 0.06$ & $29.70 \pm 0.03$ & $33.16 \pm 0.03$ \\
\hline & $0.016 \mathrm{ng} / \mu \mathrm{L}$ & $33.49 \pm 0.05$ & $32.15 \pm 0.06$ & $35.26 \pm 0.48$ \\
\hline & $3.2 \mathrm{pg} / \mu \mathrm{L}$ & - & $34.42 \pm 0.23$ & - \\
\hline & $0.64 \mathrm{pg} / \mu \mathrm{L}$ & - & - & - \\
\hline & $0.128 \mathrm{pg} / \mu \mathrm{L}$ & - & - & - \\
\hline & $25.6 \mathrm{fg} / \mu \mathrm{L}$ & - & - & - \\
\hline
\end{tabular}

Cq values above 35 were considered as negative results

Mean $C q \pm S D$ mean of the three threshold cycles of each dilution $(\mathrm{Cq}) \pm$ standard deviation (SD) 

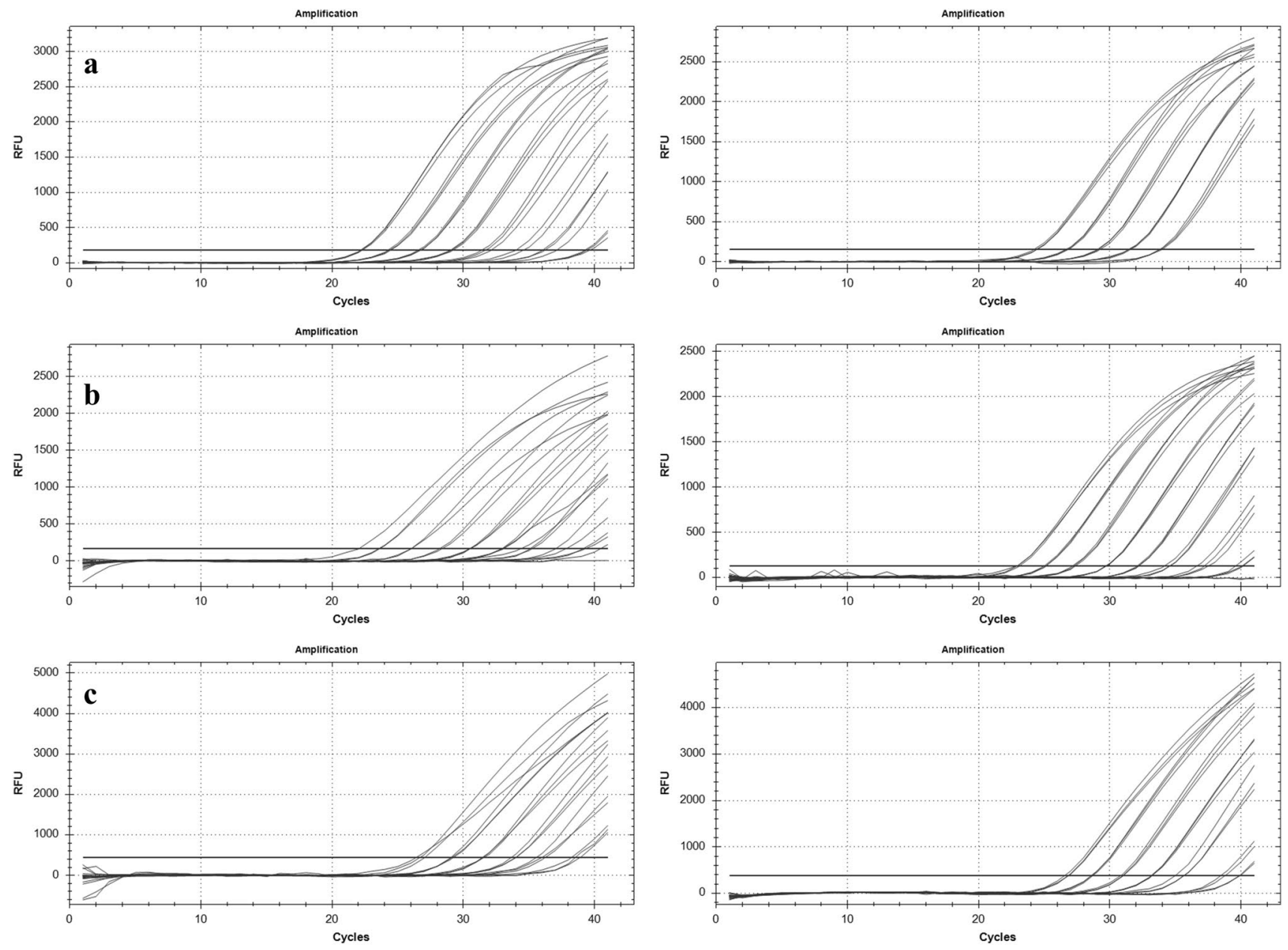

Fig. 4 a X. compactus, b X. crassiusculus, $\mathbf{c}$ X. germanus. Amplification curves of qPCR Probes. Curves of amplification on the left are relative to adult samples, those on the right, to artificial frass samples

In recent years, many biomolecular diagnostic tools able to discriminate the presence and to identify insect pests were developed: termites (Ide et al. 2016a), bugs and cicadids (Bouwer et al. 2014; Bracalini et al. 2015), moths (Onah et al. 2016; Kang et al. 2019), wood-boring beetles (Ide et al. 2016b; Cognato et al. 2020; Rizzo et al. 2021). The biomolecular identification methods can be efficient and allow a prompt implementation of control strategies (EFSA 2020) for the detection and eradication of quarantine pests (Augustin et al. 2012; Landi et al. 2017; Rizzo et al. 2020a).

Our study was focused on developing a sensitive and performing diagnostic molecular method able to univocally identify the three Xylosandrus species.

The developed qPCR Probe protocol guarantees specificity as well as robustness and can be easily performed on unidentified samples, adults or larvae, suspected to belong to the Xylosandrus genus (or Scolytinae subfamily). The novel approach of the current protocol lies in the possibility of using twig segments including part of the gallery (in the case of $X$. compactus) or wood chips removed around the exit hole (in the case of $X$. germanus) as a performing matrix for DNA extraction. Further investigations will be devoted to a better clarification of these opportunities, which allow the identification of a xylophagous insect in the absence of living stages and with exiguous quantities of frass. To date, we can underline the excellent yield of the DNA extraction method applied to a challenging matrix such as wood. It will be useful, in the future, to test the efficiency of this method also in different substrates such as softwoods. The proposed test is probably more expensive than the classical morphological approach, even if the use of taxonomic keys is more time consuming 

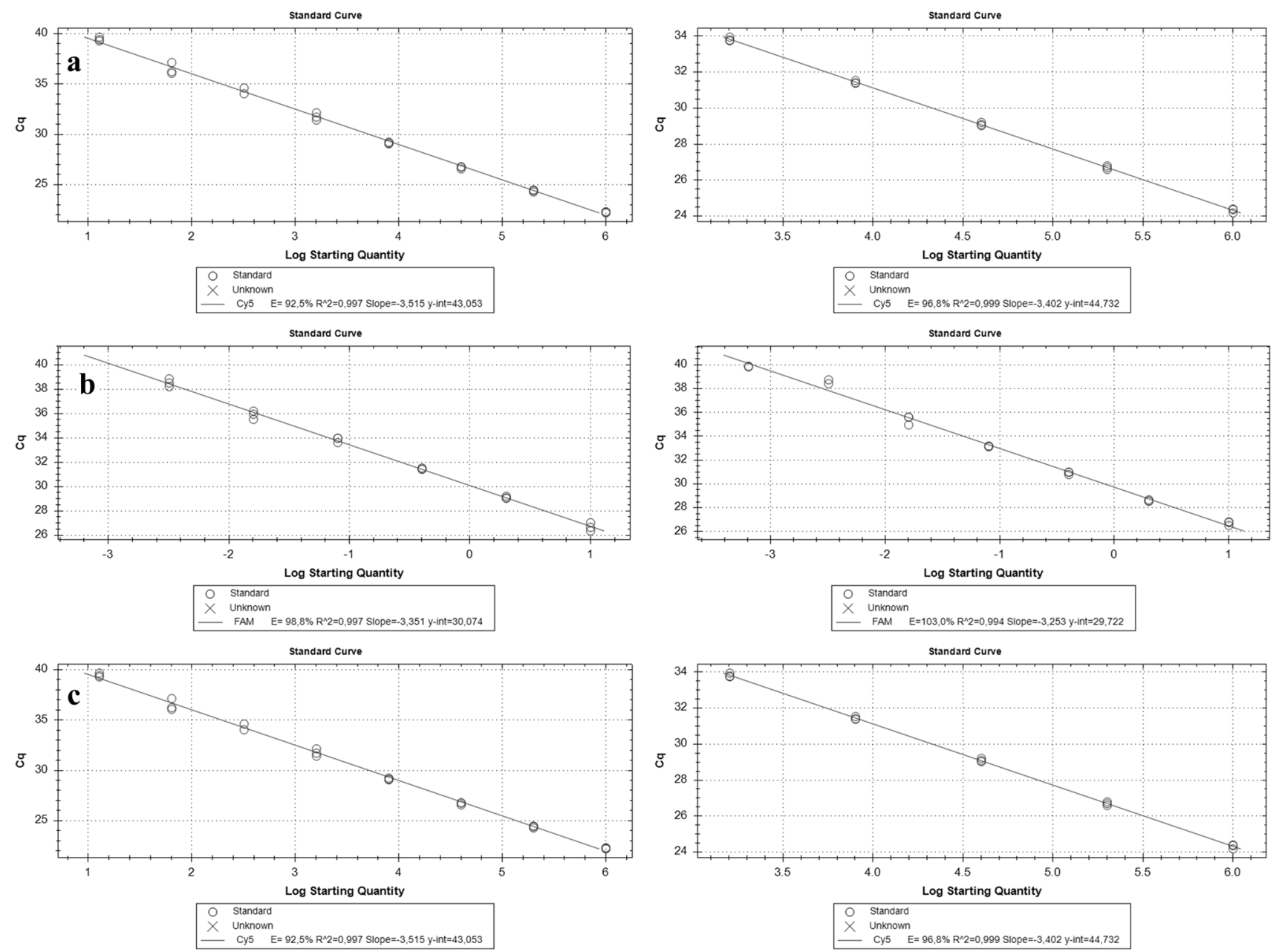

Fig. 5 a X. compactus, b X. Crassiusculus, c X. germanus. Calibration curves of the serial diluition 1:5; adult samples (on the left) and woody samples (on the right)

in many cases, as it is influenced by sample quality and available taxonomic expertise. This laboratory approach requires no more than $2 \mathrm{~h}$ from the beginning of DNA extraction to the evaluation of qPCR Probe results. The developed extractive protocol gave excellent results, taking about $50 \mathrm{~min}$ to process up to 24 single insect samples. The validation parameters provided good values in terms of specificity, sensitivity and diagnostic accuracy, confirming the more than satisfactory performance of the qPCR probe. The individual LoD (analytical sensitivity) of the method was also satisfactory, although not dependent on the starting matrix, providing evidence of its reliability (Rizzo et al. 2020a). Although the protocols suggested in this study are not economical and require good quality laboratory equipment, their optimal sensitivity even in the case of frass or wood chips samples needs to be remarked. In fact, the use of minimal quantities of these biological samples allows the identification of a species in the absence of any developmental stage (adult or larva), simplifying and speeding up the controls, and allowing the interception of a species in a higher number of cases. This tool could be of fundamental importance for phytosanitary controls at points of entry or in outbreaks of these species.

This contribution aims to be the first in a series in view of creating a molecular key for the Xylosandrus species present in Europe. 
Table 6 Repeatability and reproducibility values (mean \pm SD) on 10 replicates of DNA extract from adults and frass of the three Xylosandrus species; the average Cq of qPCR reaction for the three species of Xylosandrus genus and the correspondent standard deviations are reported

\begin{tabular}{|c|c|c|c|c|c|c|c|}
\hline \multirow[t]{3}{*}{ Species } & \multicolumn{4}{|l|}{ Adult } & \multicolumn{3}{|l|}{ Frass } \\
\hline & \multirow[t]{2}{*}{ Samples } & \multicolumn{2}{|l|}{ Repeatability } & \multirow[t]{2}{*}{ Reproducibility } & \multicolumn{2}{|l|}{ Repeatability } & \multirow[t]{2}{*}{ Reproducibility } \\
\hline & & Assay 1 & Assay 2 & & Assay 1 & Assay 2 & \\
\hline \multirow[t]{10}{*}{ X. compactus } & 1 & $20.05 \pm 1.41$ & $20.85 \pm 0.18$ & $20.89 \pm 0.15$ & $25.16 \pm 4.11$ & $28.25 \pm 0.05$ & $27.91 \pm 0.23$ \\
\hline & 2 & $21.03 \pm 0.08$ & $20.81 \pm 0.01$ & $20.88 \pm 0.13$ & $28.01 \pm 0.54$ & $28.13 \pm 0.18$ & $28.05 \pm 0.01$ \\
\hline & 3 & $20.96 \pm 0.20$ & $20.89 \pm 0.19$ & $20.90 \pm 0.14$ & $27.74 \pm 0.87$ & $28.06 \pm 0.01$ & $27.69 \pm 0.33$ \\
\hline & 4 & $20.17 \pm 0.77$ & $20.54 \pm 0.55$ & $20.65 \pm 0.43$ & $27.71 \pm 0.89$ & $28.23 \pm 0.34$ & $28.04 \pm 0.04$ \\
\hline & 5 & $20.41 \pm 0.02$ & $20.82 \pm 0.13$ & $20.82 \pm 0.09$ & $28.52 \pm 0.14$ & $27.86 \pm 0.22$ & $27.90 \pm 0.09$ \\
\hline & 6 & $20.34 \pm 1.02$ & $21.11 \pm 0.28$ & $21.03 \pm 0.24$ & $28.61 \pm 0.71$ & $27.86 \pm 0.01$ & $27.87 \pm 0.08$ \\
\hline & 7 & $20.83 \pm 0.27$ & $20.92 \pm 0.15$ & $20.87 \pm 0.11$ & $27.39 \pm 1.05$ & $28.18 \pm 0.09$ & $27.97 \pm 0.25$ \\
\hline & 8 & $21.00 \pm 0.10$ & $21.06 \pm 0.04$ & $21.00 \pm 0.11$ & $28.38 \pm 0.05$ & $27.85 \pm 0.33$ & $27.76 \pm 0.15$ \\
\hline & 9 & $21.34 \pm 0.90$ & $20.68 \pm 0.06$ & $20.78 \pm 0.19$ & $26.99 \pm 1.82$ & $28.16 \pm 0.01$ & $27.92 \pm 0.23$ \\
\hline & 10 & $21.71 \pm 1.46$ & $20.64 \pm 0.25$ & $20.77 \pm 0.29$ & $27.73 \pm 1.23$ & $27.77 \pm 0.08$ & $28.01 \pm 0.02$ \\
\hline \multirow[t]{10}{*}{ X. crassiusculus } & 1 & $22.36 \pm 0.20$ & $22.40 \pm 0.08$ & $22.31 \pm 0.15$ & $30.81 \pm 0.01$ & $30.83 \pm 0.01$ & $30.76 \pm 0.11$ \\
\hline & 2 & $22.27 \pm 0.03$ & $22.01 \pm 0.11$ & $22.08 \pm 0.15$ & $33.2 \pm 0.02$ & $33.27 \pm 0.01$ & $32.40 \pm 1.50$ \\
\hline & 3 & $22.11 \pm 0.28$ & $22.04 \pm 0.06$ & $22.10 \pm 0.12$ & $30.63 \pm 0.00$ & $30.63 \pm 0.00$ & $31.11 \pm 0.84$ \\
\hline & 4 & $22.24 \pm 0.17$ & $21.85 \pm 0.25$ & $21.94 \pm 0.24$ & $30.75 \pm 0.11$ & $30.67 \pm 0.00$ & $30.66 \pm 0.02$ \\
\hline & 5 & $22.24 \pm 0.14$ & $22.07 \pm 0.13$ & $22.03 \pm 0.11$ & $32.68 \pm 0.83$ & $32.09 \pm 0.01$ & $31.61 \pm 0.82$ \\
\hline & 6 & $22.18 \pm 0.04$ & $22.12 \pm 0.07$ & $22.15 \pm 0.07$ & $30.27 \pm 0.52$ & $29.90 \pm 0.01$ & $31.01 \pm 1.94$ \\
\hline & 7 & $22.93 \pm 0.85$ & $22.14 \pm 0.14$ & $22.13 \pm 0.10$ & $30.76 \pm 0.12$ & $30.84 \pm 0.01$ & $30.84 \pm 0.01$ \\
\hline & 8 & $22.73 \pm 0.86$ & $22.25 \pm 0.12$ & $22.19 \pm 0.13$ & $33.26 \pm 0.01$ & $33.28 \pm 0.01$ & $33.28 \pm 0.01$ \\
\hline & 9 & $22.11 \pm 0.16$ & $22.31 \pm 0.05$ & $22.25 \pm 0.10$ & $30.81 \pm 0.01$ & $30.83 \pm 0.01$ & $30.79 \pm 0.07$ \\
\hline & 10 & $22.27 \pm 0.03$ & $22.29 \pm 0.49$ & $22.27 \pm 0.35$ & $33.26 \pm 0.02$ & $33.27 \pm 0.01$ & $32.43 \pm 1.45$ \\
\hline \multirow[t]{10}{*}{ X. germanus } & 1 & $22.5 \pm 0.28$ & $22.45 \pm 0.08$ & $22.31 \pm 0.15$ & $25.63 \pm 0.69$ & $23.56 \pm 0.49$ & $24.25 \pm 1.38$ \\
\hline & 2 & $22.5 \pm 0.28$ & $22.09 \pm 0.11$ & $22.23 \pm 0.15$ & $24.52 \pm 0.96$ & $24.53 \pm 1.61$ & $24.53 \pm 2.27$ \\
\hline & 3 & $22.25 \pm 0.04$ & $21.99 \pm 0.06$ & $22.12 \pm 0.12$ & $25.45 \pm 0.11$ & $25.12 \pm 0.08$ & $25.23 \pm 0.22$ \\
\hline & 4 & $21.91 \pm 0.40$ & $22.03 \pm 0.25$ & $22.12 \pm 0.24$ & $24.27 \pm 0.01$ & $24.24 \pm 0.01$ & $24.25 \pm 0.02$ \\
\hline & 5 & $22.36 \pm 0.24$ & $22.16 \pm 0.13$ & $22.03 \pm 0.11$ & $25.81 \pm 0.75$ & $23.56 \pm 0.53$ & $24.31 \pm 1.50$ \\
\hline & 6 & $22.34 \pm 0.20$ & $22.17 \pm 0.07$ & $22.15 \pm 0.07$ & $23.49 \pm 0.58$ & $23.56 \pm 0.41$ & $24.65 \pm 1.16$ \\
\hline & 7 & $22.15 \pm 0.05$ & $22.24 \pm 0.14$ & $22.13 \pm 0.10$ & $29.91 \pm 2.34$ & $22.89 \pm 1.65$ & $25.23 \pm 4.68$ \\
\hline & 8 & $23.53 \pm 1.20$ & $22.16 \pm 0.12$ & $22.19 \pm 0.13$ & $25.37 \pm 0.26$ & $24.59 \pm 0.18$ & $24.85 \pm 0.52$ \\
\hline & 9 & $23.33 \pm 1.21$ & $22.34 \pm 0.05$ & $22.25 \pm 0.10$ & $27.64 \pm 1.17$ & $24.14 \pm 0.82$ & $25.31 \pm 2.33$ \\
\hline & 10 & $22.00 \pm 0.22$ & $22.63 \pm 0.49$ & $22.27 \pm 0.35$ & $28.29 \pm 1.39$ & $24.13 \pm 0.98$ & $25.52 \pm 2.78$ \\
\hline
\end{tabular}

Acknowledgements The authors are grateful to the collegues of the Plant Protection Phytosanitary Service of Tuscany supporting the field collection of insect samples and frass. Thanks are due also to prof. Tiziana Panzavolta of DAGRI, University of Florence for the Xylosandrus specimens given.

Author contributions Conceptualization of the research approach, detailed laboratory methodologies, experimental designs for this study were developed and conducted by DR (principal investigator) with the assistance of DDL, LB and CS. All sample preparations, data collection and statistical analyses of data collected from DNA extracts were completed by DR, DDL, LB, DDN, AA and CS. DR, APG, FP, FB, $\mathrm{VF}$ and ER wrote the manuscript and formatted the draft. Revisions of manuscripts were completed by all authors.

Funding Open access funding provided by Università di Pisa within the CRUI-CARE Agreement.

\section{Declarations}

Conflict of interest On behalf of all authors, the corresponding author states that there is no conflict of interest.

Ethical approval This article does not contain any studies with human participants or animals (vertebrates) performed by any of the Authors.

Open Access This article is licensed under a Creative Commons Attribution 4.0 International License, which permits use, sharing, adaptation, distribution and reproduction in any medium or format, as long as you give appropriate credit to the original author(s) and the source, provide a link to the Creative Commons licence, and indicate if changes were made. The images or other third party material in this article are included in the article's Creative Commons licence, unless indicated otherwise in a credit line to the material. If material is not included in 
the article's Creative Commons licence and your intended use is not permitted by statutory regulation or exceeds the permitted use, you will need to obtain permission directly from the copyright holder. To view a copy of this licence, visit http://creativecommons.org/licenses/by/4.0/.

\section{References}

Agnello AM, Breth DI, Tee EM, Cox KC, Villani SM, Ayer KM, Wallis AE, Donahue DJ, Combs DB, Davis AE, Neal JA, English-Loeb FM (2017) Xylosandrus germanus (Coleoptera: Curculionidae: Scolytinae) occurrence, fungal associations, and management trials in New York apple orchards. J Econ Entomol 110(5):21492164. https://doi.org/10.1093/jee/tox189

Augustin S, Boonham N, Kogel WJ, Donner P, Faccoli M, Lees DC, Marini L, Mori N, Petrucco Toffolo E, Quilici S, Roques A, Yart A, Battisti A (2012) A review of pest surveillance techniques for detecting quarantine pests in Europe. EPPO Bull 42:515-551. https://doi.org/10.1111/epp.2600

Bateman C, Šigut M, Skelton J, Smith KE, Hulcr J (2016) Fungal associates of the Xylosandrus compactus (Coleoptera: Curculionidae, Scolytinae) are spatially segregated on the insect body. Environ Entomol 45(4):883-890. https://doi.org/10.1093/ee/nvw070

Blaser S, Diem H, von Felten A, Gueuning M, Andreou M, Boonham N, Tomlinson J, Müller P, Utzinger J, Frey JE, Bühlmann A (2018) From laboratory to point-of-entry: development and implementation of a LAMP-based genetic identification system to prevent introduction of quarantine insect species. Pest Manag Sci 74:1504-1512. https://doi.org/10.1002/ps.4866

Bosso L, Senatore M, Varlese R, Ruocco M, Garonna AP, Bonanomi G, Mazzoleni S, Cristinzio G (2012) Severe outbreak of Fusarium solani on Quercus ilex vectored by Xylosandrus compactus. J Plant Pathol 94(4):S4.99

Bouget C, Noblecourt T (2005) Short-term development of ambrosia and bark beetle assemblages following a windstorm in French broadleaved temperate forests. J Appl Entomol 129(6):300-310. https://doi.org/10.1111/j.1439-0418.2005.00970.x

Bouwer N, Midgley JM, Timm AE, Villet MH (2014) Successful identification of the final instar nymph of Quintilia carinata (Thunberg) (Hemiptera: Cicadidae) by DNA extraction from the exuvium. J Nat Hist 48:937-943. https://doi.org/10.1080/ 00222933.2013 .836759

Bracalini M, Cerboneschi M, Croci F, Panzavolta T, Tiberi R, Biancalan CI, Macconi S, Tegli S (2015) Alien pest molecular diagnostics: can DNA traces be exploited to assess the damage caused by the western conifer seed bug on stone pine fructification? Bull Insectol 68(1):51-60

Bruge H (1995) Xylosandrus germanus (Blandford, (1894) [Belg. Sp. nov.] (Coleoptera Scolytidae). Bull Ann Soc r belge Ent 131:249-264

CABI (2019a) Xylosandrus crassiusculus (Asian ambrosia beetle). Data sheet. Online at https://www.cabi.org/isc/datasheet/57235. Accessed 10 Jan 2021

CABI (2019b) Xylosandrus germanus (black timber bark beetle), Data sheet. Online at http://www.cabi.org/isc/datasheet/57237. Accessed 10 Jan 2021

CABI (2020) Xylosandrus compactus (shot-hole borer). Data sheet. Online at https://www.cabi.org/isc/datasheet/572354. Accessed 10 Jan 2021

Cognato AI, Sari G, Smith SM, Beaver RA, Li Y, Hulcr J, Jordal BH, Kajimura H, Lin C-S, Pham TH, Singh S, Sittichaya W (2020) The essential role of taxonomic expertise in the creation of DNA databases for the identification and delimitation of Southeast
Asian ambrosia beetle species (Curculionidae: Scolytinae: Xyleborini). Front Ecol Evol 8:27. https://doi.org/10.3389/fevo.2020. 00027

Contarini M, Vannini A, Giarruzzo F, Faccoli M, Morales-Rodriguez C, Rossini L, Speranza S (2020) First record of Xylosandrus germanus (Blandford) (Coleoptera: Curculionidae, Scolytinae) in the Mediterranean scrubland in Southern Italy, and its co-presence with the co-generic species $X$. compactus (Eichhoff) and X. crassiusculus (Motschulsky). EPPO Bull 50(2):311-315. https://doi. org/10.1111/epp.12660

Dole SA, Cognato AI (2010) Monographic revision of Xylosandrus Reitter (Coleoptera: Curculionidae: Scolytinae). Proc Calif Acad Sci 61:451-545

Dole SA, Jordal BH, Cognato AI (2010) Polyphyly of Xylosandrus Reitter inferred from nuclear and mitochondrial genes (Coleoptera: Curculionidae: Scolytinae). Mol Phylogenetics Evol 54:773782. https://doi.org/10.1016/j.ympev.2009.11.011

Dutto M, Ferracini C, Faccoli M (2018) Gravi infestazioni di Xylosandrus germanus (Blandford, 1894) (Coleoptera: Curculionidae, Scolytinae) in Castagneti Del Piemonte. Forest@ 15:112-116 (In Italian)

Dzurenko M, Ranger CM, Hulcr J, Galko J, Kanuch P (2020) Origin of non-native Xylosandrus germanus, an invasive pest ambrosia beetle in Europe and North America. J Pest Science. https://doi. org/10.1007/s10340-020-01283-x

de la Peña E, Schrader G, Vos S, EFSA (European food safety agency) (2019) Pest survey card on Aromia bungii. EFSA 16(12):25. https://doi.org/10.2903/sp.efsa.2019.EN-1731

EPPO (European plant protection organization) (2019) PM 7/98 (4) Specific requirements for laboratories preparing accreditation for a plant pest diagnostic activity. EPPO Bull 49(3):530-563. https:// doi.org/10.1111/epp.12629

EPPO (2020) European plant protection organization Technical Document No. 1081, EPPO study on the risk of bark and ambrosia beetles associated with imported non-coniferous wood. EPPO Paris available at https://www.eppo.int/RESOURCES/eppo_publicatio ns. Accessed 10 Jan 2021

Francardi V, Noal A, Francescato S, Pinto R, Bruni A, Loffredi L, Bucini D, Guarnieri D, Bellantuono M, Esposito N, Nuccitelli L, Binazzi F, Vitale F, Di Giambattista G, Roversi PF, Pennacchio F (2017) Coexistence of Xylosandrus crassiusculus (Motschulsky) and $X$. compactus (Eichhoff) (Coleoptera Curculionidae Scolytinae) in the national park of Circeo (Lazio, Italy). Redia 100:149-155. https://doi.org/10.19263/REDIA-100.17.19

Galko J, Dzurenko M, Ranger CM, Kulfan J, Kula E, Nikolov C, Zúbrik M, Zach P (2019) Distribution, habitat preference, and management of the invasive ambrosia beetle Xylosandrus germanus (Coleoptera: Curculionidae, Scolytinae) in European forests with an emphasis on the West Carpathians. Forests 10:10. https://doi. org/10.3390/f10010010

Gallego D, Lencina JL, Mas H, Ceveró J, Faccoli M (2017) First record of the Granulate Ambrosia Beetle, Xylosandrus crassiusculus (Coleoptera: Curculionidae, Scolytinae), in the Iberian Peninsula. Zootaxa 4273(3):431-434. https://doi.org/10.11646/zoota xa.4273.3.7

Garonna AP, Dole SA, Saracino A, Mazzoleni S, Cristinzio G (2012) First record of the black twig borer Xylosandrus compactus (Eichhoff) (Coleoptera: Curculionidae, Scolytinae) from Europe. Zootaxa 3251:64-68. https://doi.org/10.11646/zootaxa.3251.1.5

Grousset F, Grégoire JC, Jactel H, Battisti A, Benko Beloglavec A, Hrasovec B, Hulcr J, Inward D, Orlinski A, Petter F (2020) The risk of bark and ambrosia beetles associated with imported nonconiferous wood and potential horizontal phytosanitary measures. Forests 11:342. https://doi.org/10.3390/f11030342

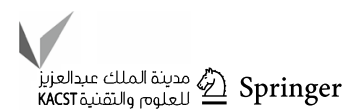


Gugliuzzo A, Criscione G, Tropea Garzia G (2019) Unusual behavior of Xylosandrus compactus (Coleoptera: Scolytinae) on carob trees in a Mediterranean environment. Insects 10:82. https://doi.org/10. 3390/insects 10030082

Gugliuzzo A, Criscione G, Biondi A, Aiello D, Vitale A, Polizzi G, Tropea Garzia G (2020) Seasonal changes in population structure of the ambrosia beetle Xylosandrus compactus and its associated fungi in a southern Mediterranean environment. PLoS ONE 15(9):e0239011. https://doi.org/10.1371/journal.pone.0239011

Henin JM, Versteirt V (2004) Abundance and distribution of Xylosandrus germanus (Blandford 1894) (Coleoptera, Scolytidae) in Belgium: new observations and an attempt to outline its range. J Pest Sci 77:57-63. https://doi.org/10.1007/s10340-003-0030-5

Hoppe B, Wilstermann A, Schrader G, Delbianco A, Vos S, EFSA (European food safety agency) (2020) Pest survey card on Xylosandrus crassiusculus. EFSA 17(7):30. https://doi.org/10. 2903/sp.efsa.2020.EN-1903

Ide T, Kanzaki N, Ohmura W, Okabe K (2016) Molecular identification of the western drywood termite (Isoptera: Kalotermitidae) by loop-mediated isothermal amplification of DNA from fecal pellets. J Econ Entomol 109:2234-2237. https://doi.org/10.1093/ jee/tow 167

Ide T, Kanzaki N, Ohmura W, Okabe K (2016) Molecular identification of an invasive wood-boring insect Lyctus brunneus (Coleoptera: Bostrichidae: Lyctinae) using frass by loop-mediated isothermal amplification and nested PCR assays. J Econ Entomol 109:14101414. https://doi.org/10.1093/jee/tow030

Inward DJG (2020) Three new species of ambrosia beetles established in Great Britain illustrate unresolved risks from imported wood. J Pest Sci 93(1):117-126. https://doi.org/10.1007/ s10340-019-01137-1

Ioos R, Fourrier C, Iancu G, Gordon TR (2009) Sensitive detection of Fusarium circinatum in pine seed by combining an enrichment procedure with a real-time polymerase chain reaction using duallabeled probe chemistry. Phytopathology 99:582-590. https://doi. org/10.1094/PHYTO-99-5-0582

Kang TH, Sunam Kim S, Hong K-J, Lee HS (2019) DNA barcoding in quarantine inspection: a case study on quarantine insect monitoring for Lepidoptera obtained through quarantine inspection on foreign vessels. Mitochondrial DNA Part B 4(1):43-48. https:// doi.org/10.1080/23802359.2018.1536447

Katoh K, Standley DM (2013) MAFFT multiple sequence alignment software version 7: improvements in performance and usability. Mol Biol Evol 30(4):772-780. https://doi.org/10.1093/molbev/ mst010

Katovich S (2004) Insects attacking black walnut in the Midwestern United States. In: CH Michler, PM Pijut, J W van Sambeek, MV Coggeshall, J Seifert, K Woeste, R Overton, and F Ponder Jr (eds.). Black walnut in a new century: Proceedings of the 6th Walnut Council Research Symposium. USFS North Central Research Station, Gen. Tech. Rep. NC-243, St. Paul, MN, Lafayette, IN: 121-126

Kiran VS, Asokan R, Revannar R, Hanchipura Mallesh MS, Ramasamy E (2019) Genetic characterization and DNA barcoding of coffee shot-hole borer, Xylosandrus compactus (Eichhoff) (Coleoptera: Curculionidae: Scolytinae). Mitochondrial DNA Part A 30(7):779-785. https://doi.org/10.1080/24701394.2019.1659249

Kirkendall LW, Biedermann PHW (2015) Evolution and diversity of bark and Ambrosia beetles. In: Vega FE, Hofstetter RW (eds) Bark beetles, biology and ecology of native and invasive species, 1 st edn. Elsevier, Academic Press, London, UK, pp 85-156

Kirkendall L, Faccoli M (2010) Bark beetles and pinhole borers (Curculionidae, Scolytinae, Platypodinae) alien to Europe. ZooKeys 56:227-251. https://doi.org/10.3897/zookeys.56.529

Landi L, Gómez D, Braccini CL, Pereyra VA, Smith SM, Marvaldi AE (2017) Morphological and molecular identification of the invasive
Xylosandrus crassiusculus (Coleoptera: Curculionidae: Scolytinae) and its South American range extending into Argentina and Uruguay. Ann Entomol Soc Am 110(3):344-349. https://doi.org/ 10.1093/aesa/sax032

Li R, Mocka R, Huang Q, Abad J, Hartung J, Kinarda G (2008) A reliable and inexpensive method of nucleic acid extraction for the PCR-based detection of diverse plant pathogens. J Virol Methods 154:48-55. https://doi.org/10.1016/j.jviromet.2008.09.008

Mayers CG, McNew DL, Harrington TC, Roeper RA, Fraedrich SW, Biedermann PHW, Castrillo LA, Reed RE (2015) Three genera in the Ceratocystidaceae are the respective symbionts of three independent lineages of ambrosia beetles with large, complex mycangia. Fungal Biol 119:10751092. https://doi.org/10.1016/j. funbio.2015.08.002

Meurisse N, Rassati D, Hurley BP, Brockerhoff EG, Haack RA (2018) Common pathways by which non-native forest insects move internationally and domestically. J Pest Sci 92:13-27. https://doi.org/ 10.1007/s10340-018-0990-0

Morales-Rodriguez C, Sferrazza I, Aleandri MP, Dalla Valle M, Speranza S, Contarini M, Vannini A (2021) The fungal community associated with the ambrosia beetle Xylosandrus compactus invading the mediterranean maquis in central Italy reveals high biodiversity and suggests environmental acquisitions. Fungal biol 125:12-24. https://doi.org/10.1016/j.funbio.2020.09.008

Onah IE, Taylor D, Eyo J, Ubachukwu P (2016) Identification of the False Codling Moth, Thaumatotibia leucotreta (Meyrick) (Lepidoptera: Tortricidae), infesting sweet oranges in Nigeria, by DNA barcoding. Proc Entomol Soc Wash 118(4):574-581. https://doi. org/10.4289/0013-8797.118.4.574

Pennacchio F, Roversi PF, Francardi V, Gatti E (2003) Xylosandrus crassiusculus (Motschulsky) a bark beetle new to Europe (Coleoptera Scolytidae). Redia 86:77-80

Pennacchio F, Santini L, Francardi V (2012) Bioecological notes on Xylosandrus compactus (Eichhoff) (Coleoptera Curculionidae Scolytinae), a species recently recorded into Italy. Redia 95:67-77

Pennacchio F, Sabbatini PG, Jucker C, Allegro G, Roversi PF (2012) A key for the identification of larvae of Anoplophora chinensis. Anoplophora glabripennis and Psacothea hilaris (Coleoptera Cerambycidae Lamiinae) in Europe. J Zool 95:57-65

Poland TM, Rassati D (2019) Improved biosecurity surveillance of non-native forest insects: a review of current methods. J Pest Sci 92:37-49. https://doi.org/10.1007/s10340-018-1004-y

Ranger CM, Reding ME, Persad AB, Herms DA (2010) Ability of stress-related volatiles to attract and induce attacks by Xylosandrus germanus and other ambrosia beetles. Agric Forest Entomol 12:177-185. https://doi.org/10.1111/j.1461-9563.2009.00469.x

Ranger CM, Tobin PC, Reding ME (2015) Ubiquitous volatile compound facilitates efficient host location by a non-native ambrosia beetle. Biol Invasions 17:675-686. https://doi.org/10.1007/ s10530-014-0758-2

Ranger CM, Reding ME, Schultz PB, Oliver JB, Frank SD, Addesso KM, Chong JH, Sampson B, Werle C, Gill S, Krause C (2016) Biology, ecology, and management of non- native ambrosia beetles (Coleoptera: Curculionidae: Scolytinae) in ornamental plant nurseries. J Integr Pest Manag 7(1):25. https://doi.org/10.1093/ jipm/pmw005

Rassati D, Faccoli M, Petrucco Toffolo E, Battisti A, Marini L (2015) Improving the early detection of alien wood-boring beetles in ports and surrounding forests. J Appl Ecol 52:50-58. https://doi. org/10.1111/1365-2664.12347

Rassati D, Battisti A, Faccoli M, Marini L (2016) Habitat and climatic preferences drive invasions of non-native ambrosia beetles in deciduous temperate forests. Biol Invasions 18:2809-2821. https://doi.org/10.1007/s10530-016-1172-8

Rassati D, Lieutier F, Faccoli M (2016) Alien wood-boring beetles in Mediterranean regions. In: Paine TD, Lieutier F (eds) Insects and 
diseases of Mediterranean forest systems. Springer International Publishing, Switzerland, pp 293-327

Reed S, Muzika RM (2010) the influence of forest stand and site characteristics on the composition of exotic dominated ambrosia beetle communities (Coleoptera: Curculionidae: Scolytinae). Env Entom 39(5):1482-1491. https://doi.org/10.1603/EN09374

Rizzo D, Taddei F, Da Lio D, Nugnes F, Barra E, Stefani L, Bartolini L, Griffo RV, Spigno P, Cozzolino L, Rossi E, Garonna AP (2020) Identification of the red-necked longhorn beetle Aromia bungii (Faldermann, 1835) (Coleoptera: Cerambycidae) with real-time PCR on frass. Sustainability 12:6041. https://doi.org/10.3390/ su12156041

Rizzo D, Taddei A, Da Lio D, Bruscoli T, Cappellini G, Bartolini L, Salemi C, Luchi N, Pennacchio F, Rossi E (2020) Molecular Identification of Anoplophora glabripennis (Coleoptera: Cerambycidae) from frass by loop-mediated isothermal amplification. J Econ Entomol 113(6):2911-2919. https://doi.org/10.1093/jee/toaa206

Rizzo D, Luchi N, Da Lio D, Bartolini L, Nugnes F, Cappellini G, Bruscoli T, Salemi C, Griffo RV, Garonna AP, Rossi E (2021) Development of a loop-mediated isothermal amplification (LAMP) assay for the identification of the invasive wood borer Aromia bungii (Coleoptera: Cerambycidae) from frass. 3 Biotech 11:85. https://doi.org/10.1007/s13205-020-02602-w

Smith SM, Beaver RA, Cognato AI (2020) A monograph of the Xyleborini (Coleoptera, Curculionidae, Scolytinae) of the Indochinese Peninsula (except Malaysia) and China. ZooKeys 983:1-442. https://doi.org/10.3897/zookeys.983.52630

Stergulc F, Frigimelica G, Zandigiacomo P, Battisti A (1999) Gravi deperimenti del noce comune in giovani impianti da legno in Friuli-Venezia Giulia. Sherwood 44:27-30 (In Italian)
Teter S, Steffen L (2017) Real-Time qPCR: guidelines for a comparison of reagent performance. Application note \#AN299. Retrieved from Promega corporation website: https://ita.promega.com/resou rces/pubhub/applications-notes/an299-real-time-qpcr-guidelinesfor-a-comparison-of-reagent-performance/.

Tuncer C, Kushiyev R, Erper I (2018) Determination of fungal flora on Anisandrus dispar Fabricius and Xylosandrus germanus Blandford (Coleoptera: Curculionidae: Scolytinae). Acta Hortic 1226:391-398. https://doi.org/10.17660/ActaHortic.2018.1226.60

Vannini A, Contarini M, Faccoli M, Della Valle M, Rodriguez CM, Mazzetto T, Guarneri D, Vettraino AM, Speranza S (2017) First report of the ambrosia beetle Xylosandrus compactus and associated fungi in the Mediterranean maquis in Italy, and new host-pest associations. Bull OEPP 47(1):100-103. https://doi.org/10.1111/ epp. 12358

Vega FE, Hofstetter RW (eds) (2015) Bark beetles, biology and ecology of native and invasive species, 1st edn. Elsevier, Academic Press, London, UK, p 640

Weber BC, McPherson JE (1983) Life history of the am-brosia beetle Xylosandrus germanus (Coleoptera: Scolytidae). Ann Entomol Soc Am 76:455-462. https://doi.org/10.1111/epp.12358

Wu Y, Trepanowski NF, Molongoski JJ, Reagel PF, Lingafelter SW, Nadel H, Myers SW, Ray AM (2017) Identification of wood-boring beetles (cerambycidae and buprestidae) intercepted in tradeassociated solid wood packaging material using DNA barcoding and morphology. Sci Rep 7:40316. https://doi.org/10.1038/srep4 0316 